\title{
SURFACE RUNOFF IN TWO REHABILITATION PERIODS OF A BAUXITE MINE
}

\author{
Aline Gonçalves Spletozer $2^{*} \odot$, Lucas Jesus da Silveira ${ }^{\circledR}$, Alexandre Simões Lorenzon ${ }^{3} \odot$, Aurora Yoshiko \\ Sato $^{4}$ and Herly Carlos Teixeira Dias ${ }^{3}$
}

${ }^{1}$ Received on 27.06.2020 accepted for publication on 14.10.2020.

${ }^{2}$ Universidade Federal de Viçosa, Programa de Pós-Graduação em Ciência Florestal, Viçosa, MG- Brasil. E-mail: <alinespletozer_afmt@ hotmail.com $>$ and $<$ ljsfloresta@hotmail.com>.

${ }^{3}$ Universidade Federal de Viçosa, Departamento de Engenhaira Florestal, Viçosa, MG- Brasil. E-mail: <alelorenzon@yahoo.com.br> and $<$ herly@ufv.br>.

${ }^{4}$ Universidade Federal de Viçosa, Departamento de Biologia Vegetal, Viçosa , MG- Brasil. E-mail: <aurorasato@gmail.com>.

*Corresponding author.

\begin{abstract}
The objective of this study was to monitor and compare runoff at 2.5 and 3.5 years of rehabilitation of a mined bauxite area with clonal planting of Eucalyptus. Seven plots were allocated for collecting runoff and precipitation was recorded with a pluviograph. The physical and environmental factors which interfere with runoff were characterized in both periods and subjected to principal component analysis (PCA) to show the most explanatory factors. The average monthly runoff percentage at 2.5 years was $0.25 \%( \pm$ $0.26 \%$ ) of precipitation and equal ( $\mathrm{p}$-value $<0.05)$ to the 3.5 years $(0.15 \pm 0.22 \%)$ of rehabilitation. Both values were lower than the Eucalyptus plantation area without mining $(0.56 \%)$ in the same region and declivity. The high vegetation cover percentage by Eucalyptus crowns and Brachiaria sp. and the high infiltration rates were the determining factors in PCA, and may explain the statistically equal runoff values between the rehabilitation periods. The combination of good edaphic conditions and the fast coverage of the plants resulted in runoff below $1 \%$ in a rehabilitated area after bauxite mining.
\end{abstract}

Keywords: Mining; Infiltration; Vegetal cover.

\section{ESCOAMENTO SUPERFICIAL EM DOIS PERÍODOS DE REABILITAÇÃO DE UMA MINA DE BAUXITA}

RESUMO - O objetivo deste estudo foi monitorar e comparar o escoamento superficial aos 2,5 e 3,5 anos de reabilitação de uma área minerada de bauxita com plantio clonal de eucalipto. Sete parcelas foram alocadas para coleta de escoamento superficial e a precipitação foi registrada com pluviógrafo. Os fatores físico-ambientais que interferem no escoamento superficial foram caracterizados nos dois períodos e submetidos à análise de componentes principais (ACP) para evidenciar os mais explicativos. $O$ escoamento superficial percentual médio mensal aos 2,5 anos foi $0,25 \%( \pm 0,26 \%)$ da precipitação e igual (p-valor $<0,05)$ ao de 3,5 anos $(0,15 \pm$ $0,22 \%)$ de reabilitação. Ambos os valores foram inferiores ao de área de plantio de Eucalyptus sem mineração (0,56\%) na mesma região e declividade. A elevada porcentagem de cobertura de vegetação, pelas copas de Eucalyptus e pela Brachiaria sp., e as elevadas taxas de infiltração foram os fatores determinantes na ACP, $e$ podem explicar os valores estatisticamente iguais de escoamento superficial entre os periodos de reabilitação. A combinação de boas condições edáficas e a rápida cobertura das plantas resultou em escoamento abaixo de $1 \%$ em uma área reabilitada, após a mineração de bauxita.

Palavras-Chave: Mineração; Infiltração; Cobertura vegetal. 


\section{INTRODUCTION}

Bauxite is among the minerals extracted in Brazil, coming from surface mines, which are also called open-pit mines (ABAL, 2018). Surface mining starts by removing vegetation and the upper soil horizons to expose the ore. After ore removal, the original waste and organic soil are replaced to reconstruct the topography of the area, and revegetation is carried out at the end (Vilas Boas et al., 2018).

The superficial mining process causes changes in the landscape such as topographical drawdown (Kuter, 2013), an increase in soil density (Barros et al., 2013), and the formation of cracks and fissures in the soil surface (Haigh and Sansom, 1999), thereby modifying hydrological processes with a reduction in runoff due to soil turning and the presence of species with high vegetation coverage (Merino-Martin et al., 2012).

The return to a similar or better functional ecosystem than that before the mining is the rehabilitation goal after surface mining (Reynolds and Reddy, 2012). A challenge in this process is controlling the water runoff (Rubio et al., 2013). Several techniques have been used to control it such as revegetation, which helps in recovering organic matter, restructuring the mined soil (Banning et al., 2008), and unpacking the soil with subsoiling, which can induce positive hydrological results in rehabilitated ecosystems when associated with revegetation (Sheoran et al., 2010). Thus, monitoring changes in soil and vegetation properties associated with hydrological processes (such as runoff) in sequential rehabilitation periods is essential to assess and improve the implemented techniques (Shrestha and Lal, 2011).

Eucalyptus has shown high survival and rapid growth in mined areas (Schiavo et al., 2010), in addition to assisting in recovering organic matter from the mined soil (Banning et al., 2008). Planting Eucalyptus in rehabilitation is conditioned to the interest of the landowner in producing wood for economic purposes (Schiavo et al., 2010). It is known that runoff in areas without mining in Minas Gerais State is between 0.5 and $3.8 \%$ of rainfall in Eucalyptus plantations (Silva et al., 2011).

Runoff has been monitored in surface mines, mainly in China, the United States and Spain through field experiments by installing plots in situ under simulated (Gomez-Gonzalez et al., 2016) and natural rain conditions (Merino-Martin et al., 2012), or by estimates using precipitation data (Liang et al., 2019; Taylor et al., 2009). However, only one study on the efficiency of micro-damming in retaining runoff has been recorded in Brazil (Rubio et al., 2013). The lack of runoff monitoring in mining areas in Brazil may be related to the lack of requirements in legislation and procedures related to the environmental licensing process (Jeber and Profeta, 2018).

Therefore, the objective of this study was to monitor runoff in a rehabilitated area with clonal planting of Eucalyptus 2 years after interrupting a bauxite mining operation; to compare the runoff of 2.5 years with 3.5 years of rehabilitation; and to characterize the physical-environmental factors which interfere in runoff, seeking to discriminate those which can be improved.

\section{MATERIALS AND METHODS}

\subsection{Study area}

The study was carried out in a rehabilitated bauxite mine ( $\left.21^{\circ} 3^{\prime} 57.84^{\prime \prime} \mathrm{S}, 42^{\circ} 35^{\prime} 42.38^{\prime \prime} \mathrm{W}\right)$ in the municipality of Miraí, southeastern Minas Gerais, Brazil (Figure 1A). The climate of the region is subtropical in altitude (Cwb) according to the Köppen classification with two well-defined seasons, namely a rainy summer and a dry winter. Annual rainfall is $1,336 \mathrm{~mm}$ and average annual temperature is $19.3^{\circ} \mathrm{C}$ (Alvares et al., 2013). The original vegetation type is Semi-deciduous Seasonal forest and a stratified physiognomy of the Atlantic Forest which loses 25$50 \%$ of the canopy leaves in the dry period (Arruda et al., 2018). The predominant original soils are typical dystrophic Red-Yellow Latosol (Borges, 2013). The relief is rugged with hills and bauxite tops, forming part of the range of granulitic rocks called "Complexo Juiz de Fora" (Lopes and Adilson, 1990).

The mine of the rural property was leased by the mining company and the bauxite was extracted from July 2013 to July 2014. The ore removal was preceded by soil stripping with subsequent return to the topographic reconformation stage in August 2014. Revegetation was subsequently performed in December of the same year, following the operating standard of the mining company which is specific to the mined soils in the region (Lopes and Barros,

Revista Árvore 2021;45:e4505 


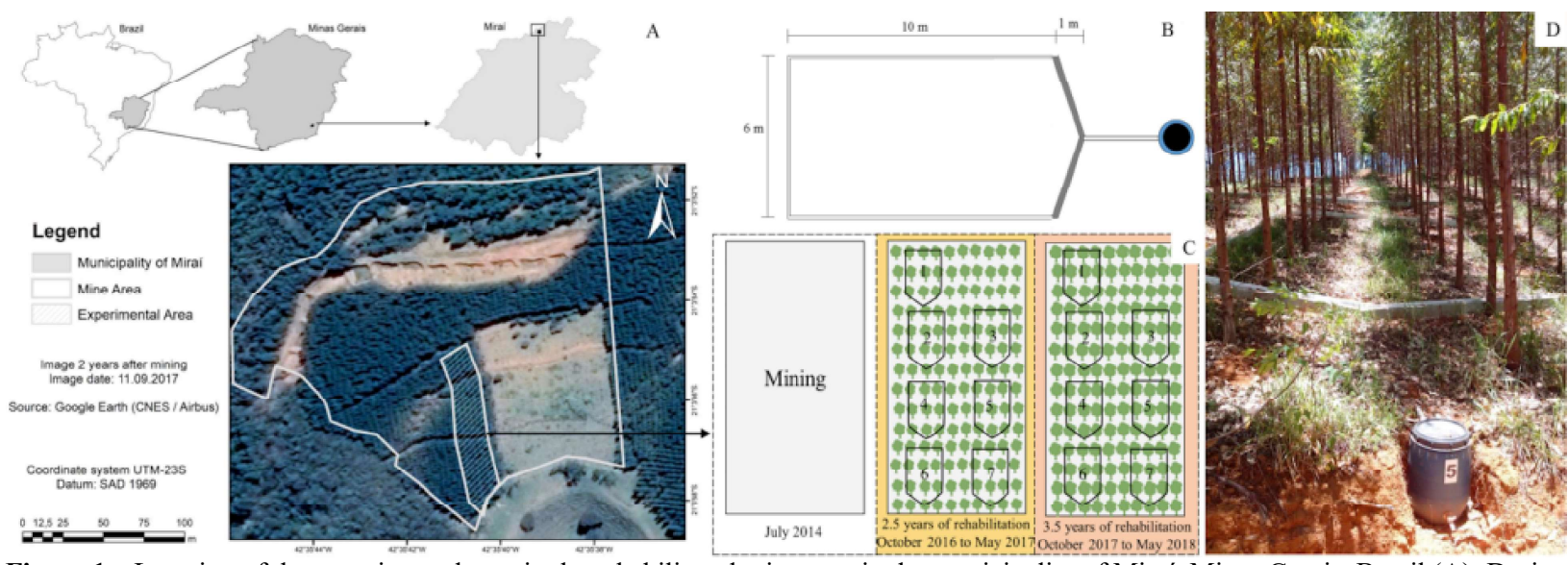

Figure 1 - Location of the experimental area in the rehabilitated mine area in the municipality of Miraí, Minas Gerais, Brazil (A); Design of the collection plots for surface runoff (B), sketch of the experimental design (C) and field installed plot (D).

Figura 1 - Localização da área experimental na área da mina reabilitada no município de Miraí, Minas Gerais, Brasil (A); Estrutura das parcelas de coleta do escoamento superficial (B), croqui do design experimental (C) e parcela instalada in situ (D).

2017). The procedure starts with liming $\left(4,000 \mathrm{~kg} \mathrm{ha}^{-1}\right.$ of dolomitic limestone) and phosphorus fertilization $\left(2,000 \mathrm{~kg} \mathrm{ha}^{-1}\right.$ of reactive natural phosphate) to be carried out before planting. The clonal planting of Eucalyptus (hybrid AEC I144) at 2 × 3 m spacing was performed at a level with application of 300 grams of NPK (04-14-08) per seedling (Lopes and Barros, 2017). Brachiaria sp. was manually sown between the planting rows. The maintenance silvicultural treatments were replanting, covering fertilization and controlling ants (Lopes and Barros, 2017).

\subsection{Surface runoff}

A total of seven runoff collecting plots were installed in October 2016 in the experimental area inside the rehabilitated bauxite mine. Runoff was monitored from October 2016 to May 2018. The seven plots had dimensions of $10 \times 6 \mathrm{~m}$ plus a triangular taper of $1 \mathrm{~m}$ in height from its base. The area and slope of the plots were: plot 1: $61.90 \mathrm{~m}^{2}$ and 12.2 $2^{\circ}$; plot 2: $61.96 \mathrm{~m}^{2}$ and $12.7^{\circ}$; plot $3: 62.22 \mathrm{~m}^{2}$ and $14.5^{\circ}$; plot $4: 62.04 \mathrm{~m}^{2}$ and $12.9^{\circ}$; plot 5: 61.64 $\mathrm{m}^{2}$ and $13.8^{\circ}$; plot $6: 61.73 \mathrm{~m}^{2}$ and $15.1^{\circ}$; and plot 7: $61.46 \mathrm{~m}^{2}$ and $15.4^{\circ}$. The plots were delimited by polyvinyl chloride (PVC) sheets and a triangular bottleneck was constructed with bricks at the lowest altitude (flow direction) for directing the water. A pipe was installed at the end of the triangular bottleneck to conduct the flow to a container with a capacity of 100 liters (Figure 1B and 1D). The water volume drained in the plots was measured after rain events, with each collection consisting of one or more rains and then the collections for each month were added to obtain the monthly total. The runoff was calculated considering the runoff volume in relation to the contribution area of each plot (Equation 1):

$R=V / A$

Where: $\mathrm{R}=$ runoff $(\mathrm{mm}) ; \mathrm{V}=$ flow water volume (L); $\mathrm{A}=$ plot area $\left(\mathrm{m}^{2}\right)$.

The runoff was divided by the precipitation to obtain the runoff coefficient and multiplied by 100 to obtain the runoff in percentage (RP). Runoff was monitored in a calendar year (January to December 2017) and compared between 2.5 years (October 2016 to May 2017) and 3.5 years (October 2017 to May 2018) of rehabilitation, both monitored periods under natural rain (Figure 1C).

\subsection{Measurement of factors which interfere with surface runoff}

Precipitation: The amount $(\mathrm{P})$ and intensity (I) of precipitation were measured by a pluviograph (RainLog 2.0 RainLog 2.0 model from RainWise ${ }^{\mathbb{R}}$ Inc) installed $50 \mathrm{~m}$ from the experimental area. The daily precipitation data $(\mathrm{mm})$ were exported in an Excel spreadsheet and added to obtain the monthly total. The intensity data $\left(\mathrm{mm} \cdot \mathrm{h}^{-1}\right)$ were used to obtain the maximum monthly intensities.

Vegetation cover: The plant stem circumference at the height of $1.30 \mathrm{~m}$ and the projection radius of the crowns were measured with a tape measure to

\section{Revista Árvore 2021;45:e4505}


calculate the diameter at breast height $(\mathrm{DBH})$ and the crown area (Wink et al., 2012), and to characterize the Eucalyptus coverage in three plots previously selected at 2.5 (February 2017) and 3.5 years (February 2018) of rehabilitation.

Litter: Three litter samples at 2.5 (May 2017) and 3.5 years (May 2018) of rehabilitation were collected to check the litter water retention capacity (LWRC). A $0.25 \mathrm{~m}^{2}$ square template was launched at three randomly selected points within a range 1.5 $\mathrm{m}$ away from the runoff collecting plots to collect the litter deposited on the soil surface. The saturated mass (after being submerged in water for 72 hours) and the dry mass (in an oven at $75^{\circ} \mathrm{C}$ with forced air circulation) of the samples were measured to calculate the LWRC by Equation 2:

\section{$\mathrm{LWRC}=(\mathrm{LSM}-\mathrm{LDM}) / \mathrm{LDM}$}

Where: $\mathrm{LWRC}=$ litter water retention capacity $(\mathrm{kg} / \mathrm{kg}) ; \mathrm{LSM}=$ litter saturated mass $(\mathrm{kg}) ; \mathrm{LDM}=$ litter dried mass $(\mathrm{kg})$.

Physical properties of the soil: The texture, the overall density (Ds), the macro (ma) and microporosity (mi), the total porosity (TP) and the particle density (Pd) of the soil at 2.5 and 3.5 years of rehabilitation were analyzed to characterize their physical attributes (Teixeira et al., 2017).

Water infiltration into the soil: The initial infiltration rate (IIR), infiltration capacity (IC) and the stable infiltration rate (SIR) were measured in situ by the double ring infiltrometer method using an IN2-W infiltrometer from Turf-TecInternational ${ }^{\circ}$. The top layer of litter was removed to measure the water infiltration rates into the soil. The tests were conducted until the infiltration rate was constant in at least three consecutive measurements, reaching the stable infiltration rate (SIR). Three trials were performed at 2.5 (May 2017) and 3.5 years (May 2018) of rehabilitation. Soil moisture at a depth of 0 to $20 \mathrm{~cm}$ was measured by the gravimetric method (Teixeira et al., 2017) on the respective test days and compared by the t-test $(\mathrm{p} \leq 0.05)$ before comparing the infiltration rates. The infiltration rate was calculated by the relation between the infiltrated water column by time interval (Equation 3 ):

$I R=\Delta h / \Delta t$

Where: $\mathrm{IR}=$ Infiltration rate $\left(\mathrm{mm} \mathrm{h}^{-1}\right) ; \mathrm{h}=$ height of the infiltrated column of water $(\mathrm{mm}) ; \mathrm{t}=$ time interval to infiltrate the water column (hours).
The initial infiltration rate (IIR) was the rate measured in the first instant of the test. The infiltration capacity (IC) was considered the maximum rate that the soil can absorb water after the infiltration stabilized in a given time interval. The water slide height value was transformed into IC by Equation 4:

$I C=60 h A c / t A c$

Where: $\mathrm{IC}=$ infiltration capacity $\left(\mathrm{mm} \mathrm{h}^{-1}\right) ; \mathrm{hAc}=$ height of the accumulated infiltrated column of water $(\mathrm{mm}) ; \mathrm{tAc}=$ accumulated time interval $(\mathrm{min})$.

Mechanical resistance of soil to penetration: The mechanical resistance of the soil to penetration was measured using an automated SoloTrack PLG5300 penetrograph from Falker $^{\circledR}$. Six observations were made to characterize the mechanical resistance of the soil to penetration at 2.5 (March 2017) and 3.5 years (March 2018) of rehabilitation. Soil moisture (0 to $20 \mathrm{~cm}$ ) was measured by the gravimetric method (Teixeira et al., 2017) on the respective test days.

\subsection{Statistical analysis}

The data normality of the monthly runoff in percentage (RP), litter water retention capacity (LWRC), litter dry mass (LDM), physical characteristics of the soil, initial (IIR) and stable (SIR) infiltration rate and infiltration capacity (IC) was analyzed by the Shapiro-Wilk test and analyzes of variance were performed to verify the differences in these parameters between the 2.5 years with the 3.5 years of rehabilitation. The Scott-Knott test $(\mathrm{p} \leq 0.05)$ was applied to group similar soil mechanical resistance to penetration values in each rehabilitation period. Pearson linear correlation $\left(r^{2}\right)$ between runoff and precipitation was calculated to verify its influence on runoff $(\mathrm{p} \leq 0.05)$.

A principal component analysis (PCA) was applied to the dataset of the factors which interfere with surface runoff to check the interrelated variables and highlight the factors with the greatest influence. The factors used in the PCA were: precipitation $(\mathrm{P})$, initial infiltration rate (IIR), stable infiltration rate (SIR), infiltration capacity (IC), mechanical resistance of the soil to penetration (RSP), overall soil density (Ds), soil particle density (Dp), total porosity (TP), macroporosity (ma), microporosity (mi), vegetation cover area (VCA) and litter water retention capacity (LWRC). 
The data were entered and processed in Microsoft Excel and the statistical analyses were performed using the R program (R Core Team, 2020).

\section{RESULTS}

\subsection{Runoff and precipitation}

The total precipitation in 2017 was $1,152 \mathrm{~mm}$, generating a cumulative total of $3.3 \mathrm{~mm}$ of runoff in the area rehabilitated with Eucalyptus after bauxite mining, meaning that $0.29 \%$ of the rainfall was converted into runoff. The average monthly runoff percentage was $0.14 \%$. The largest runoff occurred in November $(2.1 \mathrm{~mm})$, corresponding to $0.65 \%$ of the $317.4 \mathrm{~mm}$ of precipitation. The lowest precipitation $(1.8 \mathrm{~mm})$ and absence of the runoff were in September. The lowest runoff was between June and October, with an average of $0.01 \%$ of rainfall. These months were characterized by the lowest precipitation intensities of $0.63 \mathrm{~mm} \mathrm{~h}^{-1}$ (Figure 2A).

The average monthly runoff percentage at 2.5 years was $0.25 \%( \pm 0.26 \%)$ of precipitation and equal ( $p$-value $<0.05)$ to 3.5 years $(0.15 \pm 0.22 \%)$ of rehabilitation. This runoff percentage varied between months and was higher in February $(0.68 \%)$ and November $(0.65 \%)$ at 2.5 and 3.5 years of rehabilitation, respectively (Figure $2 \mathrm{~B}$ ). The runoff in the rainy season at 2.5 years of rehabilitation (October to May) was $5.0 \mathrm{~mm}(0.42 \%)$ for $1,193 \mathrm{~mm}$ of precipitation. Moreover, the surface runoff in the same months at 3.5 years was $2.5 \mathrm{~mm}(0.20 \%)$ for 1,292 $\mathrm{mm}$ precipitation. The maximum and minimum values of runoff occurred in different months at 2.5 and 3.5 years of rehabilitation. The maximum
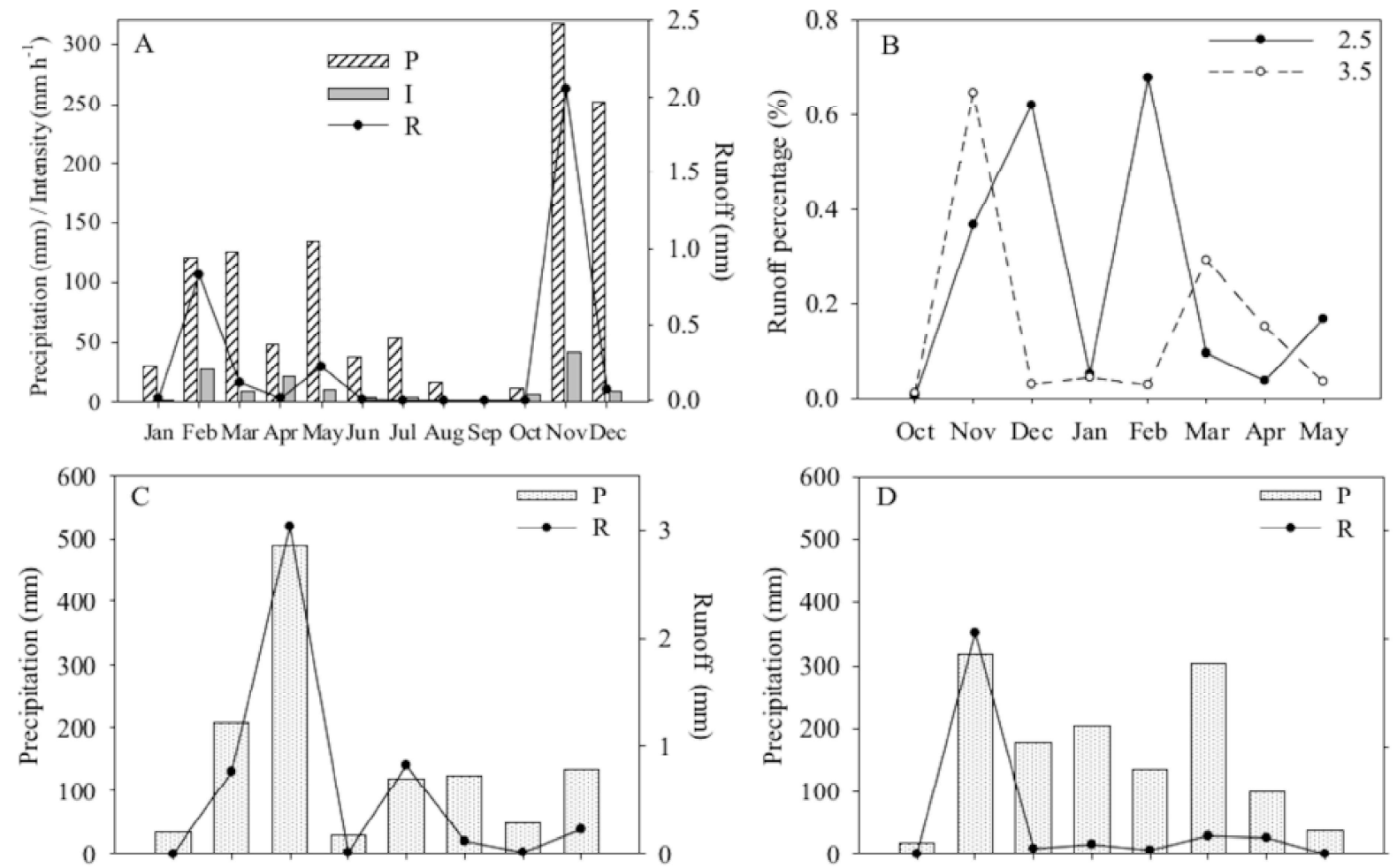

Oct Nov Dec Jan Feb Mar Apr May

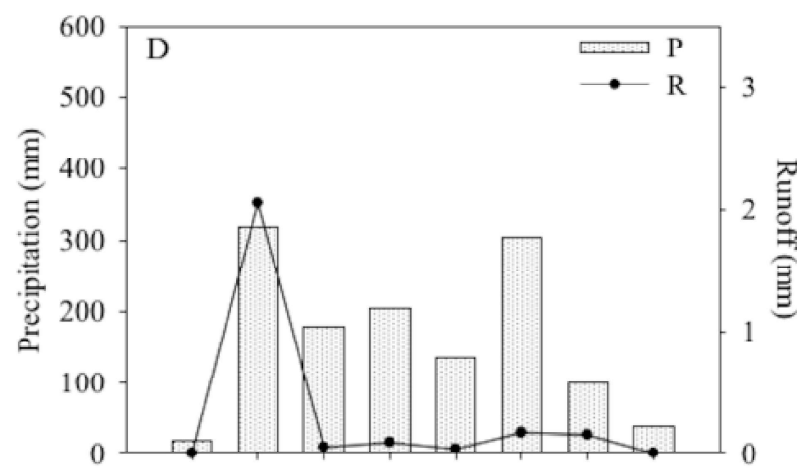

Oct Nov Dec Jan Feb Mar Apr May

Figure 2 - Precipitation (P), maximum precipitation intensity (I) and runoff (R) in 2017 (A); Runoff percentage (\%) at 2.5 years (October 2016 to May 2017) and at 3.5 years of rehabilitation (October 2017 to May 2018) (B); Precipitation (mm) and monthly runoff (mm) at 2.5 years (October 2016 to May 2017) (C); and at 3.5 years of rehabilitation (October 2017 to May 2018) (D) in the municipality of Miraí, Minas Gerais, Brazil.

Figura 2 - Precipitação (P), intensidade de precipitação máxima (I) e escoamento superficial (ES) no ano de 2017 (A); Escoamento superficial percentual (\%) aos 2,5 anos (outubro de 2016 a maio de 2017) e aos 3,5 anos de reabilitação (outubro de 2017 a maio de 2018) (B); Precipitação (mm) e escoamento superficial mensal (mm) aos 2,5 anos (outubro de 2016 a maio de 2017) (C); e aos 3,5 anos de reabilitação (outubro de 2017 a maio de 2018) (D) no município de Miraí, Minas Gerais, Brasil. 
runoff $(3.1 \mathrm{~mm})$ at 2.5 years of rehabilitation was in December for a precipitation of $489 \mathrm{~mm}$, while the minimum was in January with $30 \mathrm{~mm}$ of precipitation and $0.01 \mathrm{~mm}$ of runoff. The maximum runoff $(2.1$ $\mathrm{mm}$ ) for 3.5 years of rehabilitation was in February, which constituted $0.64 \%$ of the rains in that month $(317 \mathrm{~mm})$. In contrast, the minimum runoff $(0.001$ $\mathrm{mm}$ ) was in October, equivalent to $0.01 \%$ of the rains of $18 \mathrm{~mm}$ (Figure 2C and 2D).

\subsection{Factors which interfere with surface runoff}

The vegetation cover area estimated by the projection area of the Eucalyptus crowns increased $27 \%$ from 2.5 years to 3.5 years of rehabilitation. The mean stem diameter increased from $10.94 \mathrm{~cm}( \pm 1.60$ $\mathrm{cm})$ to $12.09 \mathrm{~cm}( \pm 1.99 \mathrm{~cm})$, and was equivalent to a basal area of $15.95 \mathrm{~m}^{2} \mathrm{ha}^{-1}$ and $19.55 \mathrm{~m}^{2} \mathrm{ha}^{-1}$ for 2.5 and 3.5 years of rehabilitation, respectively (Table 1).

Rehabilitation at 3.5 years of age showed a higher mean ( $\mathrm{p}$-value $<0.05)$ accumulated litter mass $\left(14.53 \pm 1.79 \mathrm{Mg} \mathrm{ha}^{-1}\right)$ than at 2.5 years $(8.07 \pm 0.85$ $\left.\mathrm{Mg} \mathrm{ha}{ }^{-1}\right)$. A greater water retention of accumulated litter was found at 3.5 years $\left(2.39 \pm 0.13 \mathrm{~kg} \mathrm{~kg}^{-1}\right)$ than at 2.5 years $\left(1.91 \pm 0.11 \mathrm{~kg} \mathrm{~kg}^{-1}\right)$ after bauxite mining (Table 1).
The substrate humidity at 2.5 years $(16.20 \% \pm$ $1.33 \%)$ was equal to 3.5 years $(17.08 \% \pm 1.70 \%)$ of rehabilitation on the days of the infiltration tests. The initial infiltration (184 and $\left.198 \mathrm{~cm} \mathrm{~h}^{-1}\right)$, infiltration capacity $\left(124.4\right.$ and $\left.88.7 \mathrm{~cm} \mathrm{~h}^{-1}\right)$ and stable infiltration rate $\left(105.1\right.$ and $\left.109.4 \mathrm{~cm} \mathrm{~h}^{-1}\right)$ did not differ ( $p$-value $\leq 0.05$ ) between sampling of 2.5 and 3.5 years of rehabilitation (Table 1).

The physical analysis of the soil showed that the clay content, soil density, particle density, microporosity and total porosity were equal between the rehabilitation periods. In contrast, the sand content increased and the macroporosity decreased at 3.5 years (Table 1).

The soil moisture at the time of the soil resistance to penetration test of 2.5 years $(19.60 \pm 0.063 \%)$ was equal to that of 3.5 years $(21.59 \pm 0.47 \%)$ of rehabilitation. The reconstructed soil reached the maximum penetrograph resistance $(6,800 \mathrm{kPa})$ in the six samples in both periods, but this resistance was reached at greater depths at 3.5 years (Figure $3 \mathrm{~A}$ and 3B). The average soil resistance of 2.5 years $(4900.02$ $\mathrm{kPa})$ was equal ( $\mathrm{p}$-value $\leq 0.05)$ to 3.5 years $(4756.87$ $\mathrm{kPa})$ of rehabilitation. The lowest resistances were at

Table 1 - Vegetable cover area (VCA), diameter at breast height (DBH) and basal area (BA) of trees stem, average saturated mass (Mg $\left.\mathrm{ha}^{-1}\right)$ and average dry mass $\left(\mathrm{Mg} \mathrm{ha}^{-1}\right)$ of accumulated litter and litter water retention capacity $(\mathrm{LWRC})\left(\mathrm{kg} \mathrm{kg}^{-1}\right)$, initial infiltration rate (IIR), stable infiltration rate (SIR), infiltration capacity (IC) and physical soil properties.

Tabela 1 - Área de projeção das copas (APC), diâmetro do fuste (dap) e área basal (AB) do tronco das árvores, massa saturada média (Mg $\mathrm{ha}^{-1}$ ) e massa seca média $\left(\mathrm{Mg} \mathrm{ha}^{-1}\right)$ da serapilheira acumulada e capacidade de retenção hidrica (CRH) da serapilheira ( $\left.\mathrm{kg}_{\mathrm{kg}}{ }^{-1}\right)$, taxa de infiltração inicial (TII), taxa de infiltração estável (TIE), capacidade de infiltração (CI) e propriedades físicas do solo.

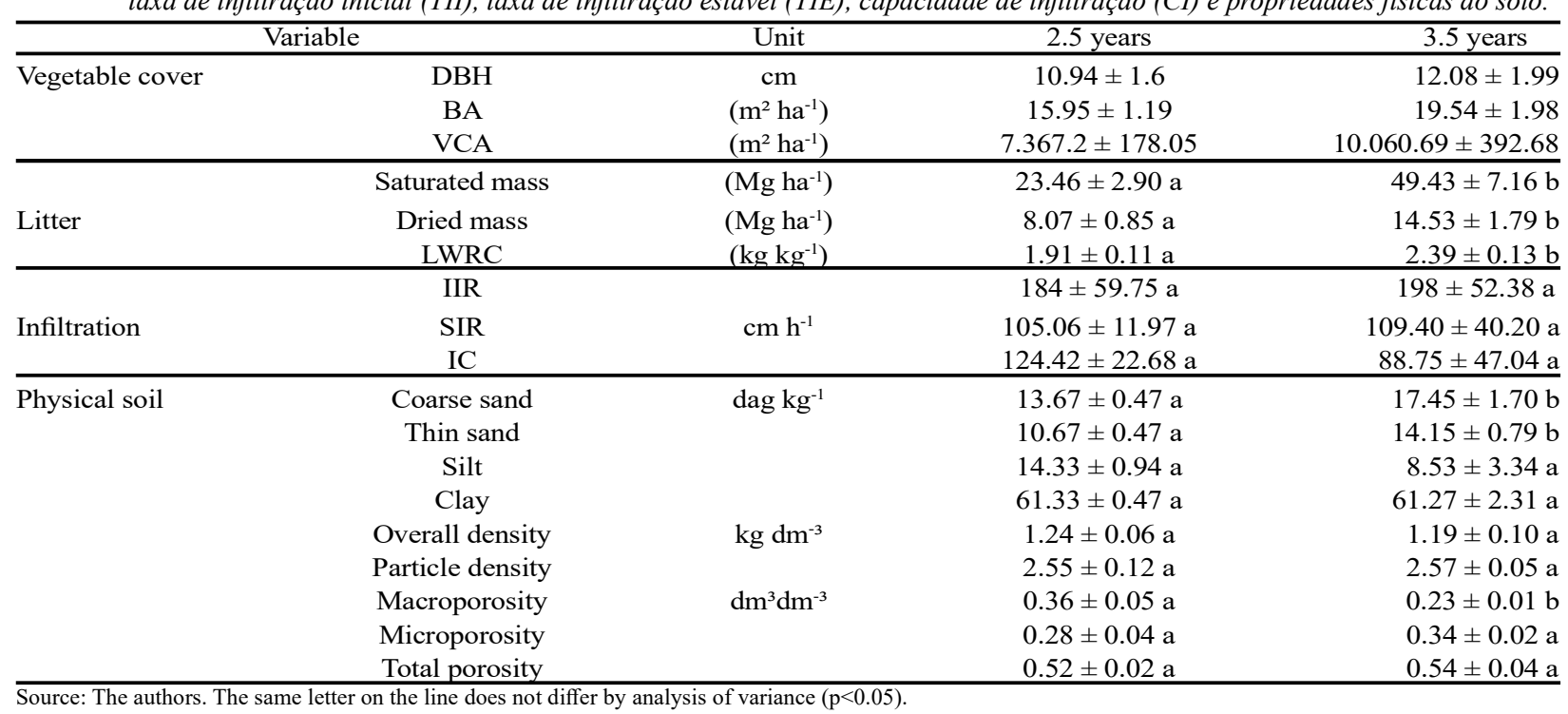

Fonte: Os autores. Mesma letra na linha não difere pela análise de variância $(p<0,05)$.

Revista Árvore 2021;45:e4505 
depths of 10 and $20 \mathrm{~cm}$, with $30,40,50$ and $60 \mathrm{~cm}$ being the most resistant in both periods (Figure $3 \mathrm{C}$ and 3D).

\subsection{Correlation coefficients and principal component analysis}

Positive correlations between runoff and precipitation and a reduction in this coefficient were observed from $2.5(0.96$; p-value 0.001$)$ to 3.5 years (0.61; p-value 0.105).

The principal components analysis of the factors which interfered in the runoff at 2.5 years of age after bauxite mining explained $69.10 \%$ of the total variability in the first two components, where $44.70 \%$ was explained by Component 1. Precipitation, rate and infiltration capacity, macro and microporosity were the most explanatory factors in Component 1 . Furthermore, soil density and vegetation cover had the highest eigenvectors in Component 2 (24.4\%) (Figure 4A). After 3.5 years of rehabilitation, the first two components explained $75.90 \%$ of the total variability, while $39.40 \%$ of the variance was explained by Component 1 and $36.50 \%$ by Component 2 . Precipitation, vegetation cover, soil density and total porosity, macro and micro porosity were the most explanatory variables in the $39.40 \%$ explanation of Component 1 . Infiltration rates and capacity were the most explanatory in Component 2 (Figure 4B).
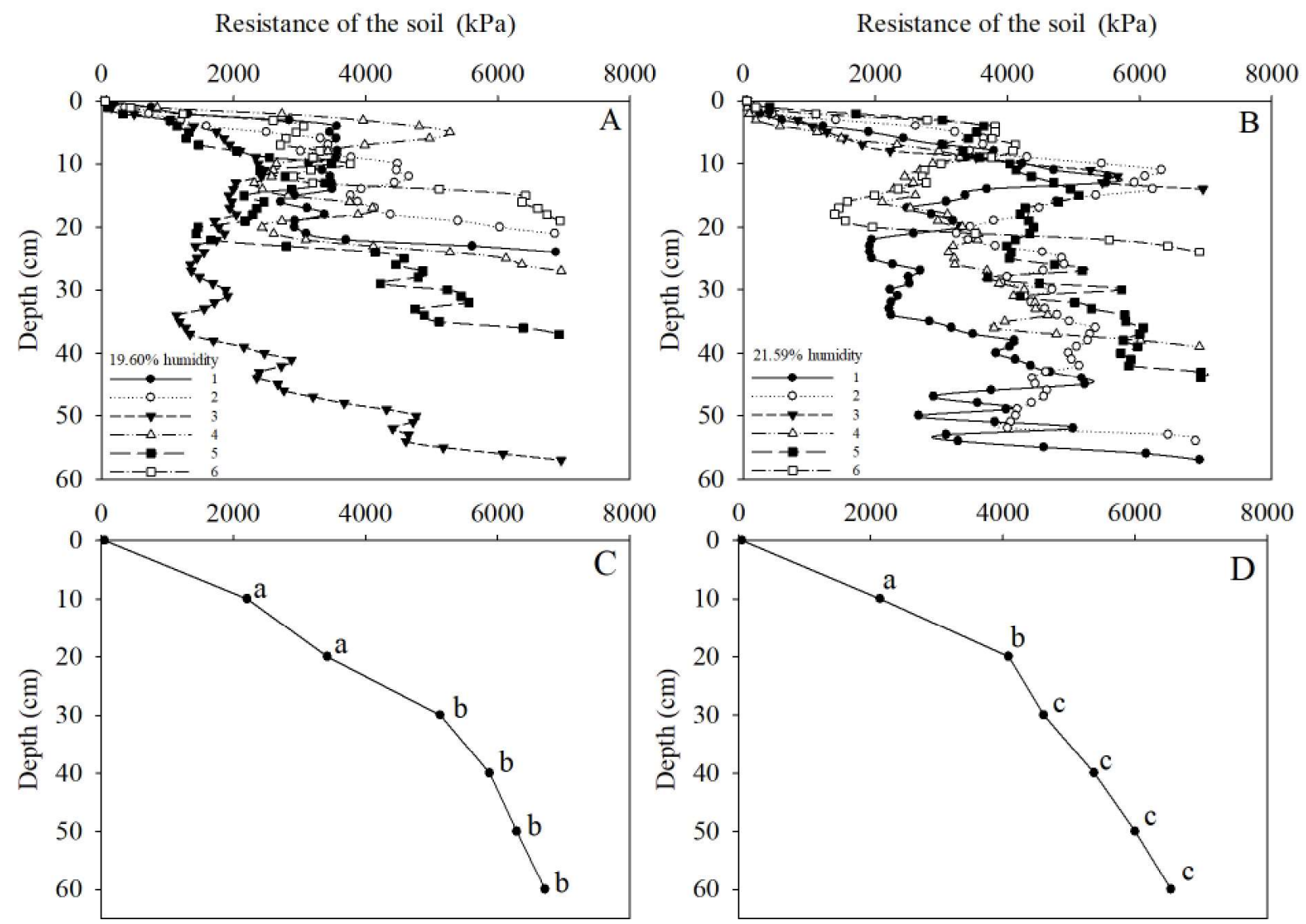

Figure 3 - Mechanical resistance of the soil to the penetration of the six samples at 2.5 years (A) and 3.5 years (B) of rehabilitation; grouping of resistances at 2.5 years (C) and 3.5 years (D) of rehabilitation. Similar letters indicate groupings of soil resistance between depths in the same treatment by the Scott-Knott test $(\mathrm{p}$-value $<0.05)$.

Figura 3 - Resistência mecânica do solo à penetração das seis amostragens aos 2,5 anos (A) e aos 3,5 anos (B) de reabilitação; agrupamento das resistências aos 2,5 anos $(C)$ e aos 3,5 anos (D) de reabilitacão. Letras similares indicam agrupamentos da resistência do solo entre as profundidades no mesmo tratamento pelo teste de Scott Knott (p-valor <0,05). 

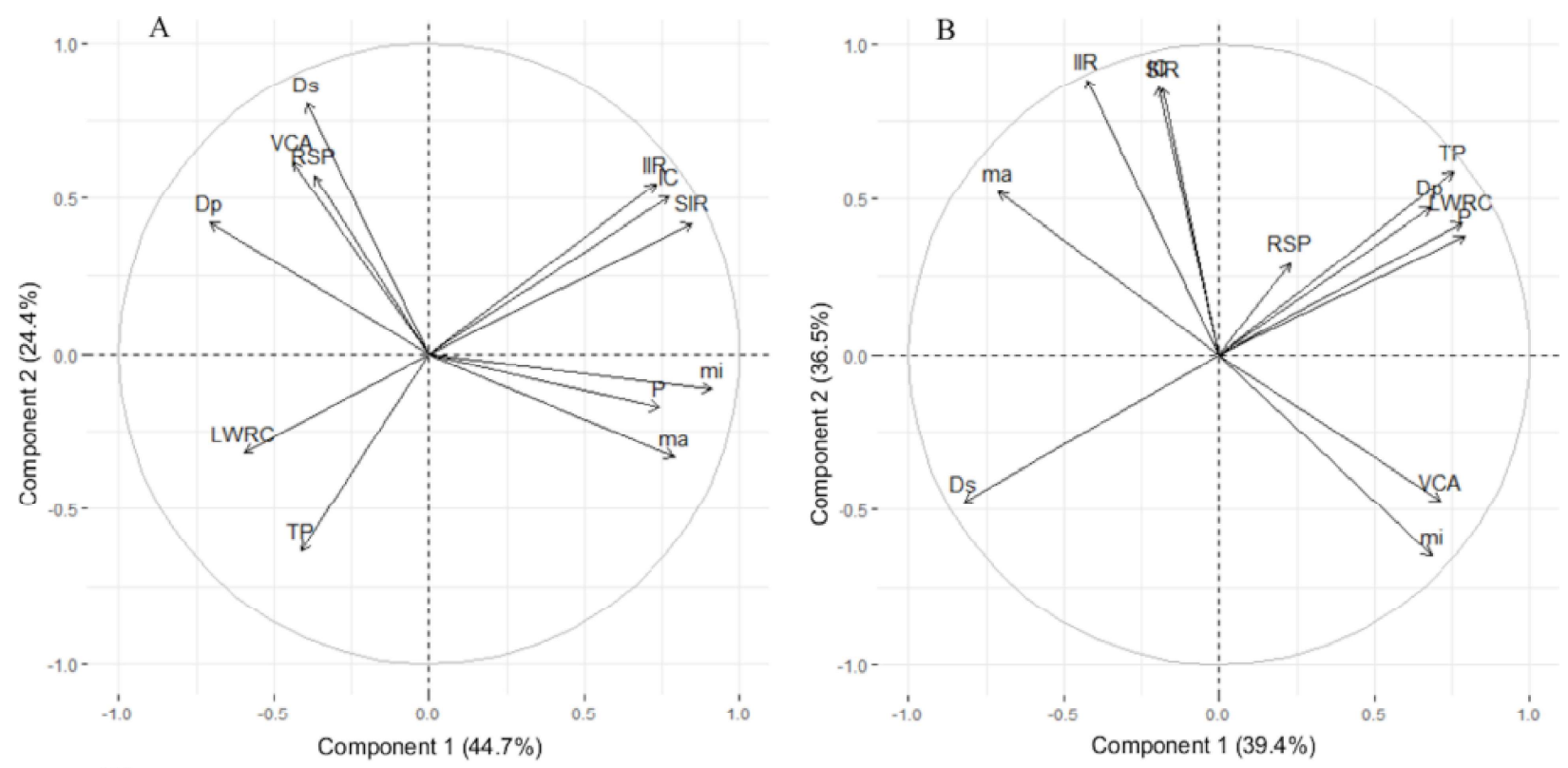

Where:

$\mathrm{Dp}=$ soil particle density

Ds $=$ overall soil density

IC = infiltration capacity

IIR = initial infiltration rate

LWRC = litter water retention capacity

ma= macroporosity

$\mathrm{mi}=$ microporosity

RSP = resistance of the soil $\mathrm{P}=$ precipitation

$\mathrm{SIR}=$ stable infiltration rate TP $=$ total porosity

$\mathrm{VCA}=$ vegetation cover area

Figure 4 - Principal components analysis for the physical-environmental factors which interfere with runoff at 2.5 (A) and 3.5 (B) years of rehabilitation after bauxite mining in the municipality of Miraí, Minas Gerais, Brazil.

Figura 4 - Analise de componentes principais para os fatores fisicos-ambientais que interferem no escoamento superficial na idade de 2,5 (A) e 3,5 (B) anos de reabilitação, após mineração de bauxita no município de Miraí, Minas Gerais, Brasil.

\section{DISCUSSION}

The total annual rainfall was $408 \mathrm{~mm}$ less than expected in the climatological normal estimated from 1981 to 2010 for the region $(1,560 \mathrm{~mm})$ (INMET, 2018). The higher runoff in November can be explained by the greater amount and intensity of precipitation that occurred in that month, which reached $41.40 \mathrm{~mm} \mathrm{~h}^{-1}$ (Dourte et al., 2015). The accumulated runoff in 2017 and in the rainy season at 2.5 and 3.5 years of rehabilitation were lower than that found in Eucalyptus plantations with a slope of $17.6 \%$ in the Vale do Rio Doce region, Minas Gerais (1.2\%) (Silva et al., 2011), and also for that reported in the rainy season in a Eucalyptus plantation with the same slope in a bauxite pre-mining area in southeastern Minas Gerais (0.56\%) (Silveira, 2017). Surface runoff lower than that of non-mined areas may indicate that a greater amount of water is infiltrating the mined soil, mainly due to the soil turning and high vegetation cover which traps the runoff, allowing greater water infiltration into the soil (Merino-Martin et al., 2012).
The similarity of the runoff between 2.5 and 3.5 years of rehabilitation after bauxite mining can be explained by the rapid establishment of vegetation in the first period ( 2.5 years) with more than $90 \%$ of the plots covered, which reduces runoff even in the early stages of rehabilitation (Carroll et al., 2004; Loch, 2000). Insignificant differences in runoff were also observed after vegetation was established in freshly mined plots in Central Queensland (Carroll et al., 2004).

The increase in the canopy projection area, diameter and basal area of Eucalyptus stem from 2.5 to 3.5 years of rehabilitation are associated with the growth dynamics of the plants which increases the occupied space over time (Wink et al., 2012). The diameter and basal area values are higher than those of Eucalyptus plantations via seeds in the region of this study (Silveira, 2017), and similar to the values of commercial plantations of the same age (Wink et al., 2012). The $27 \%$ increase in vegetation cover in one year is within expectations for the mining area, which

Revista Árvore 2021;45:e4505 
could reach $60.26 \%$ in five years, as recorded in China (Li et al., 2017). This high vegetation cover reduces runoff due to greater rainfall interception (Freitas et al., 2016; Zou et al., 2015) and decreased impact of raindrops on the soil (Armenise et al., 2018).

The greater accumulated litter stock after 3.5 years of rehabilitation can be explained by the larger size and growth of trees, which enhances the production and deposition of leaves in the soil (Mateus et al., 2013). The litter cover reduces the runoff speed, thereby facilitating rainwater infiltration into the soil (Loch, 2000).

The statistically equal values of the initial infiltration rate, infiltration capacity and stable infiltration rate between the rehabilitation periods $(2.5$ and 3.5 years, Table 1) can be explained by the similar humidity conditions and the physical properties of the soil, as reported in surface mines in Texas, United States, with infiltration rates between 3 to $22 \mathrm{~cm} \mathrm{~h}^{-1}$ (Jarocki, 1994). Greater infiltration occurs when the soil is dry and when texture and structure conditions have more empty spaces, constituting a characteristic which requires long periods for changes (Jarocki, 1994). The stable infiltration rates at 2.5 and 3.5 years of rehabilitation are considered high when compared to natural soils in Eucalyptus plantations (78 and 165 $\mathrm{mm} \mathrm{h}^{-1}$ ) and pasture (47 and $50 \mathrm{~mm} \mathrm{~h}^{-1}$ ) in Oxisols (Almeida et al., 2014; Silveira, 2017) and mined areas in Texas, United States ( 3 to $22 \mathrm{~cm} \mathrm{~h}^{-1}$ ) (Jarocki, 1994). The higher infiltration rates in this study can be explained by the thick and porous topsoil layer which facilitates water infiltration after mining (Huang et al., 2015) and by the presence of cracks and crevices resulting from the cross-subsoiling carried out during the soil preparation in rehabilitation (Haigh and Sansom, 1999).

The reduction in macroporosity and an increase in the sand content from 2.5 to 3.5 years of rehabilitation may be due to the reconstructed soil having a heterogeneous structure in the area generated by the disruption of soil horizons to remove ore ( $\mathrm{Li}$ et al., 2014). The short period (one year) between sampling at 2.5 and 3.5 years of rehabilitation was not enough to modify the other physical soil characteristics (Table 1 ), as already reported in other surface mines (Chen et al., 2011; Ngugi et al., 2017).

The reconstructed soil reached the maximum penetrograph strength due to the presence of remaining saprolite concretions after mining (Silveira, 2017). These concretions result in a higher stony index from $20 \mathrm{~cm}$ deep due to the soil horizon restructuring after mining (Barros et al., 2013). The structural similarity of the soil explains the equal mechanical resistance values of the soil to penetration between 2.5 and 3.5 years of rehabilitation (Ngugi et al., 2017). The lower strengths up to $20 \mathrm{~cm}$ in depth are explained by the replacement of the topsoil layer removed before mining (Martín-Moreno et al., 2016).

The reduction in the correlation coefficient between runoff and precipitation at 3.5 years can be explained by the increase in vegetation cover. Vegetation intercepts rain drops, reducing its direct influence of precipitation (Freitas et al., 2016; Zou et al., 2015) and contributing to reduce runoff (Zhang et al., 2014).

The largest eigenvectors for infiltration rate and capacity, macro and microporosity and soil density allow to infer that soil characteristics can be used to explain the equal runoff values (Santos et al., 2018). Except for macroporosity, these soil characteristics did not differ in the interval of one year between the rehabilitation periods (2.5 and 3.5 years), demonstrating that they demand more time for modification (Liu et al., 2017). Vegetation cover is another factor with a greater eigenvector in PCA and can explain the equal runoff values between the two rehabilitation periods due to its efficiency in reducing runoff by interception after 2.5 years of rehabilitation (Vásquez-Méndez et al., 2010). Although the collections of factors which interfere with runoff were not carried out in the same month, it is believed that the difference of a few days between collections in the same period is not significant (Liu et al., 2017), since there is a 12-month interval between collections for each period.

\section{CONCLUSION}

The runoff in the rehabilitated area after two years of bauxite mining showed the same pattern as unmined areas, with higher values in the rainiest months (November, December and February). The runoff was similar between 2.5 and 3.5 years of rehabilitation after bauxite mining, and less than the pre-mining runoff.

The physical soil characteristics showed insignificant changes between the two samplings,

\section{Revista Árvore 2021;45:e4505}


but the litter mass and its water retention capacity increased. Vegetation cover and soil characteristics, mainly infiltration rates, were the determining factors for the runoff similarity in the two periods, indicating that the combination of adequate soil management and rapid plant cover provided runoff below $1 \%$ in a rehabilitated area after bauxite mining.

\section{ACKNOWLEDGMENTS}

We wish to thank to the "Conselho Nacional de Desenvolvimento Científico e Tecnológico (CNPq)" for providing the first author with a scholarship. The authors are also grateful to "Companhia Brasileira de Alumínio (CBA)" of Miraí, Minas Gerais, Brazil for providing the experimental area and the maintenance of the experimental plots.

\section{AUTHOR CONTRIBUTIONS}

Aline Gonçalves Spletozer: Conceived and designed the analysis, collected and analysis the data and wrote the paper. Lucas Jesus da Silveira: collected and analysis the data. Alexandre Simões Lorenzon and Aurora Yoshiko Sato: technical review. Herly Carlos Teixeira Dias: Conceived and designed the analysis and technical review.

\section{REFERENCES}

ABAL - Associação Brasileira do Alumínio. Anuário estatístico alumínio. São Paulo: 2018, 92 p. [cited 2018 may 20]. Available from: http://abal.org.br/ publicacao/anuario-estatistico-abal-2018/

Almeida AQ, Ribeiro A, Paiva Rody Y, Monteiro Da Silva WC, Palha Leite F. Modeling of water infiltration in soil cultivated with eucalyptus and pasture. Revista Caatinga. 2014;27(1):148-53.

Alvares CA, Stape JL, Sentelhas PC, De Moraes Gonçalves JL, Sparovek G. Köppen's climate classification map for Brazil. Meteorologische Zeitschrift. 2013;22(6):711-28. doi:10.1127/09412948/2013/0507

Armenise E, Simmons RW, Ahn S, Garbout A, Doerr SH, Mooney SJ, Sturrockc CJ, Ritz K. Soil seal development under simulated rainfall: Structural, physical and hydrological dynamics. Journal of Hydrology. 2018;556(1):211-9. doi:10.1016/j. jhydrol.2017.10.073

Arruda DM, Schaefer CEGR, Fonseca RS, Solar RRC, Fernandes-Filho EI. Vegetation cover of Brazil in the last $21 \mathrm{ka}$ : New insights into the Amazonian refugia and Pleistocenic arc hypotheses. Global Ecology and Biogeography. 2018;27(1):47-56. doi:10.1111/geb.12646

Banning NC, Grant CD, Jones DL, Murphy D V. Recovery of soil organic matter, organic matter turnover and nitrogen cycling in a post-mining forest rehabilitation chronosequence. Soil Biology and Biochemistry. 2008;40(8):2021-31. doi:10.1016/j. soilbio.2008.04.010

Barros DA de, Pereira JAA, Ferreira MM, Silva BM, Ferreira Filho D, Nascimento G de O. Soil physical properties of high mountain fields under bauxite mining. Ciência e Agrotecnologia. 2013;37(5):41926. doi:10.1590/s1413-70542013000500005

Borges SR. Qualidade do Solo em áreas em recuperação com forrageiras e cafeeiro pósmineração de bauxita. [tese]. Viçosa, MG. Universidade Federal de Viçosa, 2013.

Carroll CA, Pink LB, Burger PB. Coalmine Rehabilitation : a Long Term Erosion and Water Quality Study on Central Queensland Coalmines. In: 13th International Soil Conservation Organisation Conference - ISCO, Brisbane: 2004, Anais. p. 1-6.

Chen Y, Li Dandan, Li Daoliang, Wu X, Zheng Y. Assessment for soil improvement benefit of land rehabilitation in dump areas. Mathematical and Computer Modelling. 2011;54(3-4):1204-12. doi:10.1016/j.mcm.2010.11.054

Dourte DR, Fraisse CW, Bartels WL. Exploring changes in rainfall intensity and seasonal variability in the Southeastern U.S.: Stakeholder engagement, observations, and adaptation. Climate Risk Management. 2015;7(1):11-9. doi:10.1016/j. crm.2015.02.001

Freitas JPO, Dias HCT, Silva E, Tonello KC. Net precipitation in a semideciduous forest fragment in Viçosa city, MG. Revista Árvore. 2016;40(5):793801. doi:10.1590/0100-67622016000500003

Gomez-Gonzalez MA, Voegelin A, Garcia-Guinea J, Bolea E, Laborda F, Garrido F. Colloidal

\section{Revista Árvore 2021;45:e4505}


mobilization of arsenic from mining-affected soils by surface runoff. Chemosphere. 2016;144(1):1123-31. doi:10.1016/j.chemosphere.2015.09.090

Haigh MJ, Sansom B. Soil compaction, runoff and erosion on reclaimed coal-lands (UK). International Journal of Surface Mining, Reclamation and Environment. 1999;13(4):135-46. doi:10.1080/09208119908944239

Huang L, Zhang P, Hu Y, Zhao Y. Vegetation succession and soil infiltration characteristics under different aged refuse dumps at the Heidaigou opencast coal mine. Global Ecology and Conservation. 2015;4(1):255-63. doi:10.1016/j. gecco.2015.07.006

INMET Instituto Nacional de Meteorologia. Normal Climatológica do Brasil 1981-2010. 2018. [cited 2018 may 20]. Available from: http://www.inmet.gov. br/portal/index.php?r=clima/normaisclimatologicas

Jarocki KE. Properties of and factors influencing infiltration rates at a reclaimed lignite mine, Freestone County, Texas [tese]. Faculty of the Graduate School of the University of Texas at Austin, 1994.

Jeber A, Profeta AL. Meio Ambiente e Mineração Recursos Minerais de Minas Gerais. Belo Horizonte 2018. [cited 2020 august 05]. Available from: http:// recursomineralmg.codemge.com.br/meio-ambientee-mineracao/\#considerações-finais

Kuter N. Reclamation of Degraded Landscapes due to Opencast Mining. In: Ozyavuz M, editor. Advances in Landscape Architecture, Londres: InTech; 2013, p. 823-58. doi:10.5772/55796

Li H, Lei J, Wu J. Evolution analysis of vegetation cover under the disturbance of rare earth mining: A case in Lingbei mining area. Journal of Applied Science and Engineering. 2017;20(3):393-400. doi:10.6180/jase.2017.20.3.14

Li Y, Wen H, Chen L, Yin T. Succession of bacterial community structure and diversity in soil along a chronosequence of reclamation and re-vegetation on coal mine spoils in China. PLoS One. 2014;9(12):124. doi:10.1371/journal.pone.0115024

Liang J, Wu K, Li Y, Wei Z, Zhuo P, Yan Q, Luo X. Impacts of Large-Scale Rare Earth
Mining on Surface Runoff, Groundwater, and Evapotranspiration: A Case Study Using SWAT for the Taojiang River Basin in Southern China. Mine Water and the Environment. 2019;38(2):268-80. doi:10.1007/s 10230-018-00587-w

Liu X, Bai Z, Zhou W, Cao Y, Zhang G. Changes in soil properties in the soil profile after mining and reclamation in an opencast coal mine on the Loess Plateau, China. Ecological Engineering. 2017;98(1):228-39. doi:10.1016/j. ecoleng.2016.10.078

Loch RJ. Effects of vegetation cover on runoff and erosion under simulated rain and overland flow on a rehabilitated site on the Meandu Mine, Tarong, Queensland. Australian Journal of Soil Research. 2000;38(2):299-312. doi:10.1071/SR99030

Lopes AT, Barros RS. Padrão Operacional: definição da forma (manual ou mecanizado) dos serviços de reabilitação ambiental (calagem, fosfatagem e plantio de sementes). 1.1. Miraí, MG: Votorantim Metais Alumínio Zona da Mata, Reabilitação Ambiental; 2017.

Lopes LM, Adilson C. Gênese da bauxita de Miraí, MG. Revista Brasileira de Geociências 1990;19(4):462-9.

Martín-Moreno C, Martín Duque JF, Nicolau Ibarra JM, Hernando Rodríguez N, Sanz Santos M, Sánchez Castillo L. Effects of Topography and Surface Soil Cover on Erosion for Mining Reclamation: The Experimental Spoil Heap at El Machorro Mine (Central Spain). Land Degradation and Development. 2016;27(2):145-59. doi:10.1002/1dr.2232

Mateus FA, do Couto Miranda C, Valcarcel R, Figueiredo PHA. Estoque e capacidade de retenção hídrica da serrapilheira acumulada na restauração florestal de áreas perturbadas na mata Atlântica. Floresta e Ambiente. 2013;20(3):336-43. doi:10.4322/floram.2013.024

Merino-Martin L, las Heras M, Perez-Domingo S, Espigares T, Nicolau JMM. Hydrological heterogeneity in Mediterranean reclaimed slopes: runoff and sediment yield at the patch and slope scales along a gradient of overland flow. Hydrology and Earth System Sciences 2012;16(5):1305-20. doi:10.5194/hess-16-1305-2012

Ngugi MR, Dennis PG, Neldner VJ, Doley D, 
Fechner N, McElnea A. Open-cut mining impacts on soil abiotic and bacterial community properties as shown by restoration chronosequence. Restoration Ecology. 2017;26(5):839-50. doi:10.1111/rec.12631

R Core Team. R: A language and environment for statistical computing. Version 4.0.0. Foundation for Statistical Computing; 2020.

Reynolds B, Reddy KJ. Infiltration rates in reclaimed surface coal mines. Water, Air, and Soil Pollution. 2012;223(9):5941-58. doi:10.1007/s11270-012$1330-2$

Rubio RF, Lazarim H, Lorca D, Vieira Ribeiro V. Surface water control in the bauxite mines of Porto Trombetas (Para, Brazil). In: Brown, A and Figueroa, L and Wolkersdorfer C, editor. Vols I II, Denver, Colorado, USA: 2013, p. 837-42.

Santos KF, Barbosa FT, Bertol I, De Souza Werner R, Wolschick NH, Mota JM. Study of soil physical properties and water infiltration rates in different types of land use. Semina:Ciencias Agrarias. 2018;39(1):87-98. doi:10.5433/1679$0359.2018 v 39$ n 1 p8 7

Schiavo JA, Martins MA, Rodrigues LA. Crescimento de mudas de Acacia mangium, Sesbania virgata e Eucalytpus camaldulensis, inoculadas com fungos micorrízicos, em casa-de-vegetação e em cava-de-extração de argila. Acta Scientiarum. Agronomy2010;32(1):171-178. doi:10.4025/ actasciagron.v32i1.7309

Sheoran V, Sheoran A, Poonia P. Soil Reclamation of Abandoned Mine Land by Revegetation: A Review. International Journal of Soil, Sediment and Water. 2010;3(2):1-20.

Shrestha RK, Lal R. Changes in physical and chemical properties of soil after surface mining and reclamation. Geoderma. 2011;161(3-4):168-76. doi:10.1016/j.geoderma.2010.12.015

Silva MA, Silva MLN, Curi N, Avanzi JC, Leite FP. Sistemas de manejo em plantios florestais de eucalipto e perdas de solo e água na região do vale do Rio Doce, MG. Ciencia Florestal. 2011;21(4):765-76. doi:10.5902/198050984520

Silveira LJ da. Escoamento superficial em áreas de mineração de bauxita pré e pós lavra, na Zona da Mata Mineira. [tese]. Viçosa, MG. Universidade Federal de Viçosa, 2017.

Taylor TJ, Agouridis CT, Warner RC, Barton CD. Runoff curve numbers for loose-dumped spoil in the Cumberland Plateau of eastern Kentucky. International Journal of Mining, Reclamation and Environment. 2009;23(2):103-20. doi:10.1080/17480930802176389

Teixeira PC, Donagemma GK, Fontana A, Teixeira WG. Manual de Métodos de Análise de Solo. 3rd ed. Brasília, DF: 2017.

Vásquez-Méndez R, Ventura-Ramos E, Oleschko K, Hernández-Sandoval L, Parrot JF, Nearing MA. Soil erosion and runoff in different vegetation patches from semiarid Central Mexico. Catena. 2010;80(3):162-9. doi:10.1016/j.catena.2009.11.003

Vilas Boas HF, Almeida LFJ, Teixeira RS, Souza IF, Silva IR. Soil organic carbon recovery and coffee bean yield following bauxite mining. Land Degradation and Development. 2018;29(6):1565-73. doi:10.1002/1dr.2949

Wink C, Monteiro JS, Reinert DJ, Liberalesso EE. Parâmetros da copa e a sua relação com o diâmetro e altura das árvores de eucalipto em diferentes idades. Scientia Forestalis. 2012;40(93):57-67.

Zhang GH, Liu G Bin, Zhang PC, Yi L. Influence of vegetation parameters on runoff and sediment characteristics in patterned Artemisia capillaris plots. Journal of Arid Land. 2014;6(3):352-60. doi:10.1007/s40333-013-0224-5

Zou CB, Caterina GL, Will RE, Stebler E, Turton D. Canopy interception for a tallgrass prairie under juniper encroachment. PLoS One 2015;10(11):1-19. doi:10.1371/journal.pone.0141422 